\title{
Clinical trials of dual-target CAR T cells, donor-derived CAR T cells, and universal CAR T cells for acute lymphoid leukemia
}

\author{
Juanjuan Zhao, Yongping Song and Delong Liu* (D)
}

\begin{abstract}
The current treatment for pediatric acute lymphoblastic leukemia (ALL) is highly successful with high cure rate. However, the treatment of adult ALL remains a challenge, particularly for refractory and/or relapsed (R/R) ALL. The advent of new targeted agents, blinatumomab, inotuzumab ozogamycin, and chimeric antigen receptor (CAR) T cells, are changing the treatment paradigm for ALL. Tisagenlecleucel (kymriah, Novartis) is an autologous CD19targeted CAR T cell product approved for treatment of R/R B cell ALL and lymphoma. In an attempt to reduce the relapse rate and treat those relapsed patients with antigen loss, donor-derived CAR T cells and CD19/CD22 dualtarget CAR T cells are in clinical trials. Gene-edited "off-the-shelf" universal CAR T cells are also undergoing active clinical development. This review summarized new clinical trials and latest updates at the 2018 ASH Annual Meeting on CAR T therapy for ALL with a focus on dual-target CAR T and universal CAR T cell trials.
\end{abstract}

\section{Background}

The current treatment for pediatric acute lymphoblastic leukemia (ALL) is highly successful with cure rate approaching $80 \%$ [1-3]. However, the treatment of adult ALL remains a challenge, particularly for refractory and/ or relapsed (R/R) ALL [4-9]. The prognosis of adults with $R / R$ ALL is still very poor. The $C R$ rate for $R / R$ ALL has remained only 29\% (range 18 to $44 \%$ ), and the median overall survival (OS) is only 4 months (range 26 months). Novel agents to improve the outcome of $R / R$ ALL are urgently needed. In recent years, tyrosine kinase inhibitors (TKI) have contributed to improvement of outcome of ALL with Philadelphia chromosomes ( $\mathrm{Ph}$ +ALL) [10-17]. In the past few years, immunotherapeutic agents including blinatumomab and inotuzumab ozogamicin have been shown to increase response rate and extend OS in patients with R/R ALL [18-38]. Another significant advance in ALL therapy came when chimeric antigen receptor (CAR)-engineered $\mathrm{T}$ cells were approved by FDA for children and young adults with $\mathrm{R} / \mathrm{R}$ ALL [39-46]. However, loss of antigen target has been reported to be a common mechanism for relapse after

\footnotetext{
* Correspondence: delong_liu@nymc.edu

The Affiliated Cancer Hospital of Zhengzhou University and Henan Cancer Hospital, 127 Dongming Road, Zhengzhou 450008, China
}

CAR $T$ cell therapy [47-51]. In an attempt to reduce the relapse rate and treat those relapsed patients with antigen loss, donor-derived CAR $\mathrm{T}$ cells and dual-target CAR T cells are in clinical trials. Gene-edited "off-the-shelf" universal CAR $\mathrm{T}$ cells are also undergoing active clinical development [52-59]. More versatile and programmable CARs are being developed [59-62]. This review summarized new clinical trials and latest updates at the 2018 ASH Annual Meeting on CAR T therapy for ALL with a focus on dual-target CAR $\mathrm{T}$ and universal CAR T cell trials.

\section{CD19-targeted CAR T cells}

Long-term outcome of CAR19 T cell therapy for R/R ALL

CARs are engineered to bind to a specific antigen leading to activation of the CAR T cells without the dual restriction traditionally conferred by specific $\mathrm{T}$ cell receptor and the major histocompatibility complex (MHC) [42, 43, 63-69]. CD19 is the most common target of CAR T cells to date [46, 70-73]. Tisagenlecleucel (tis-cel) (kymriah, Novartis) is an autologous CD19-targeted CAR T cell product approved for the treatment of $R / R \quad B$ cell $A L L$ and non-Hodgkin lymphoma (NHL) [48, 49, 74-76]. Another CAR T cell product targeting CD19 antigen, axicabtagene ciloleucel (yescarta, Kite), was approved for treatment of R/ 
$\mathrm{R}$ diffuse large cell lymphoma [50, 77-79]. To date, two distinct CAR T-associated toxicities (CARTox) are cytokine release syndrome (CRS) and CAR T-related encephalopathy syndrome (CRES) [80-83]. Prophylaxis and therapy for CARTox are important areas of pre-clinical and clinical research [80, 81, 84].

Recently a multicenter phase II study of tis-cel CAR T cell therapy for children and young adults with $R / R$ B-cell ALL was updated [49]. This update from the multicenter international trial reported a CR rate of $81 \%$ and the severe CRS rate of $77 \%$. The 1-year EFS was $50 \%$. With a median follow-up of 13.1 months, the median survival of these patients had not been reached. Tis-cel contains a CAR with 4-1BB as the costimulatory signal. The 4-1BB costimulation domain is known to be associated with longer persistence of CAR T cells and less $\mathrm{T}$ cell exhaustion. The tis-cel T cells were found to have an ongoing persistence of 20 months at the time of the report. It is known that higher leukemia burden is associated with higher CARTox, and CRS is associated with response, yet no linear relationship between CAR $\mathrm{T}$ cell dosage and response was observed.

The data from long-term follow-up of a single-center phase I study using 19-28z CAR T cell therapy for adult R/R ALL were updated in early 2018 [85]. The primary endpoint of this phase I study was safety. This study enrolled 75 patients (53 evaluable). The 53 evaluable patients have failed multiple prior therapies including prior allogeneic stem cell transplantation (allo-HSCT), blinatumomab, and TKIs in Ph+ALL. This study had a median follow-up of 29 months (range 1-65 months). The CR rate was $83 \%$, and the median OS was 12.9 months. Low disease burden correlated with better outcome. Among patients with a low bone marrow blasts $(<5 \%)$, the median OS was 20.1 months. The rate of severe CRS was $26 \%$. The CARTox after 19-28z CAR T-cell infusion was lower in patients with low disease burden as compared with those bearing a higher disease burden.

The Seattle group recently reported long-term adverse events after CD19-targeted CAR T cell infusions [86]. These events occurred or persisted beyond 90 days after the last CAR T cell infusion. Events related to disease progression were excluded. A total of 59 patients with R/R NHL and chronic lymphocytic leukemia (CLL) were included in this update. These patients survived more than a year and had at least 1-year complete follow-up data after their first CAR T cell infusion. At this report, the median follow-up was 23 months (range 13-57). These were adult patients with median age of 60 years (range 34-73). These patients had a median number of 4 lines of treatment (range 1-8). Among the 59 patients, $39 \%$ failed prior autologous (auto) hematopoietic cell transplantation (HCT), and 15\% failed prior allogeneic (allo) HCT. Interestingly, severe CARTox was not seen in these patients with CLL and NHL, with CRS grade I/ II, 64\%; grade III, 7\%; grade IV, none; and acute neurotoxicity, 34\%. Cytopenias requiring G-CSF and/ or transfusion support were among the notable long-term adverse events. In addition, $41 \%$ of the patients were reported to have severe hypogammaglobulinemia (IgG < $400 \mathrm{mg} / \mathrm{dL}$, or immunoglobulin replacement). Eight patients developed secondary malignancies, including 3 myelodysplasia, 4 non-melanoma skin cancer, and 1 non-invasive bladder cancer. It was noted that all except one with skin cancer had auto or allo HCT before CAR $\mathrm{T}$ cell therapy. Neuropsychiatric disorders, cerebro- and cardiovascular events, renal dysfunction, and respiratory disorders were among the reported long-term effects. Infection was reported in $74 \%$ of the patients, with the most common ones being the upper and lower respiratory tract infections. These long-term follow-up data confirmed that CD19-targeted CAR T cell therapy for NHL and CLL is well tolerated. Most long-term effects in these cohorts may have been related to prior or subsequent therapies since these patients have been heavily pre-treated.

These long-term outcome analyses of CAR T 19 cell therapy for R/R ALL clearly documented the efficacy of the CAR T cells in R/R ALL. Although there still lacks parallel comparison of CAR T cells and antibody-targeted therapies for R/R ALL, CAR T cells appear to have more durable response [71]. The 4-1BB containing CAR T cells appear to have relatively more durable response as well as CAR T cell persistence.

\section{CAR19 T cells used as reinduction/bridging therapy prior to allo-HSCT}

In a recent report at the 2018 ASH Annual Meeting, CD19-targeted CAR T cells were administered to 83 patients with R/R ALL with a median age of 10 years (range 2-61) [87]. High-risk patients were enrolled in this cohort, including 17 with extramedullary disease (EMD) (11 with CNS disease), 10 with BCR-ABL+, 8 with TP53 mutation, and 11 with relapsed ALL after allo-HSCT. The second-generation CARs contained either a CD28 $(n=21)$ or a $4-1 \mathrm{BB}(n=62)$ co-stimulatory domain. The patients received a single infusion of CAR $\mathrm{T}$ cells with a median dose of $1 \times 10^{5}\left(0.1-10 \times 10^{5}\right)$ cells/kg. The median follow-up was $172(27-325)$ days. The day $30 \mathrm{CR} / \mathrm{CRi}$ rate was 76/83 (91.6\%) with 70/76 (92.1\%) of them negative for MRD. One-year OS was $76.5 \%$ and RFS was $62.6 \%$. CARTox included $16 \%$ grade III-IV CRS and $12 \%$ severe CRES. There was one CAR T-related death. CR was observed in 14/17 of patients with EMD, including CR in 9/11 patients with CNS leukemia. OS was significantly longer in those without EMD (45.1\% vs $88.3 \%, p=0.0003)$. Consistent with the literature, OS was significantly better in patients with low leukemia burden (LB) (46.2\% high LB vs. $7.1 \%$ low 
LB, $p=0.001$ ). Even though no difference in CR/OS/RFS between patients with or without the BCR-ABL mutation was observed, the small sample size makes it impossible to claim that the low-dose CAR $\mathrm{T}$ therapy negated the poor prognostic factor of BCR-ABL mutation. Even though the CR/CRi was achieved in $7 / 8$ patients with TP53 mutation but relapse rate was high. The OS and RFS were significantly lower for patients with TP53 mutation. The CR/CRi rate after CAR $\mathrm{T}$ infusion was $91 \%$ in the 11 patients who relapsed after allo-HSCT. No significant GVHD was observed. Among the 76 patients with day $30 \mathrm{CR} / \mathrm{CRi}, 57$ proceeded to allo-HSCT in a median time of 2 months post CR. The 1-year OS of the CAR T-to-allo-HSCT group was better than that of the non-transplant group (OS $87.5 \%$ vs. $63.4 \%, p=0.013$ ). The median time to relapse for those non-transplanted patients was 100 days. The study included patients from age 2-61. It would be useful to compare the outcome in young patients with those in adult patients. It is unclear whether age makes any difference in this type of CAR T-bridging therapy.

Various reports have reiterated that higher CAR T cell doses are associated with better and deeper responses, yet the dose level of the infused CD19-directed CAR T cells in this study was low, which may be responsible for the rapid relapse after CAR T therapy. It was noted that a single-dose level of CAR T cells was used in these patients and majority $\mathrm{CR}$ patients proceeded quickly to allo-HSCT. Therefore, the CAR T cells in this report were used as reinduction therapy and allo-HSCT served as a consolidation therapy. This report suggests that the longer survival in these patients who received low-dose CAR T cells was the result of allo-HSCT, and the approach of using low-dose CAR $T$ cell therapy in $R / R$ ALL should only be used as a bridging/reinduction therapy. Due to the limit of the study design, it remains unclear what cell dose would be optimal for pre-allo-HSCT bridging/reinduction therapy.

In addition, it remains controversial as to whether allo-HSCT is routinely needed in those patients who achieve deep MRD negativity. In the long-term follow-up of the $53 \mathrm{R} / \mathrm{R}$ ALL patients who received CD19-28z CAR $\mathrm{T}$ therapy, 32 patients achieved MRD-negative CR [85]. Among these 32 patients, allogeneic transplantation did not lead to better survival than those who were not transplanted. In another retrospective analysis of 135 R/R ALL patients who received CD19-directed CAR T therapy followed quickly by allo-HSCT, CD19-negative relapse accounted for most relapse after allo-HSCT [88]. This analysis again argues that allo-HSCT may not effectively eliminate the CD19-negative ALL clones that evaded CAR $\mathrm{T}$ therapy. These observations suggest that additional graft-versus-leukemia effect may not be achieved by allo-HSCT following effective CAR $\mathrm{T}$ cell therapy.
Sequential, cocktail, or multi-targeted CAR T cell therapy may be of value.

\section{CD22-directed CAR T cells}

Similar to CD19, CD22 is also widely expressed in B cells and in most cases of B-ALL [89-93]. CD22 is usually retained following CD19 loss which is a common mechanism of relapse after CD19-directed CAR T cell therapy. A phase 1 trial of a new CD22-targeted CAR (CD22-CAR) with a 4-1BB domain was reported [94]. This was a dose escalation trial. The study enrolled 21 children and adults with R/R B-ALL, including 17 who failed CD19-directed immunotherapy. The response was found to be CAR $\mathrm{T}$ cell dose-dependent. CR was observed in $73 \%(11 / 15)$ of patients receiving $\geq 1 \times 10^{6}$ CD22-CAR T cells $/ \mathrm{kg}$, including all 5 patients with dim or no CD19 expression in the leukemia cells. The median remission duration was only 6 months (range 120). Mild CARTox were reported. CD22 antigen loss or diminished density was associated with the relapse.

In a recent update of this study, 43 patients were enrolled with a median age of 17.5 years ( $4-30$ years), $58 \%$ of these had CD19-negative disease, and 91\% failed prior CD19-directed therapy [95]. The updated analysis reported that prior CD22 therapy was associated with decreased CR rates, MRD negativity rates, and shorter duration of remission. Therefore, this study implies that in patients who have failed prior CD19- and CD22-directed therapies, allo-HSCT should be considered earlier rather than waiting till relapse.

\section{CD19/CD22 dual-targeted CAR T cells}

CD19-targeted CAR T cell therapy for R/R ALL has a relapse rate of approximately $50 \%$ at 1 year, and the most common mechanism of relapse is due to CD19 antigen loss. To reduce the possibility of relapse due to target antigen loss and /or mutation, dual antigen targeted CAR T cells are being developed and clinical trials have started. Dual-targeted CAR T cells can be generated either with bi-cistronic CARs that express CD19 and CD22 ScFv simultaneously in every cell or with mono-CARs that express CD19 and CD22 ScFv separately. In the latter approach, not all cells may contain both targets, and even in those cells with both CARs, the ratio of CD19 and CD22 CARs may not be 1:1. In the mono-CAR approach, the CAR T cell product is usually a mixture of three CAR T cell populations, namely, CD19-, CD22-, or CD19/22-targeted CAR T cells.

\section{Bi-cistronic CAR19 $\times 22$ dual-target T cells}

One group constructed a bi-cistronic retroviral vector encoding dual CARs against CD19 and CD22 [96]. These CARs contain an OX40 co-stimulatory domain for the CD19 CAR and a 4-1BB domain for the CD22 
CAR. To combat the low intensity of expression of CD22 in R/R ALL cells, a penta-valent CD22 CAR was designed and expressed in the bi-specific CAR $\mathrm{T}$ cells. The product, AUTO3, was tested in a phase I/II study evaluating the safety and efficacy of the CAR T cells designed to simultaneously target CD19 and CD22 [96]. In the latest update at $2018 \mathrm{ASH}$ annual meeting, 13 patients of 4-16 years of age with R/R ALL were enrolled and 10 received AUTO3 cells. It was successful to generate a product in all 13 patients. The median transduction efficiency was $16 \%$ (range 9-34\%). These patients were heavily pretreated already (median 3 prior lines of therapy), with 7 patients having failed prior allo-HSCT. One patient failed prior anti-CD19 CAR T cells, and one failed blinatumomab. Ten patients were evaluable after a minimum of 4 weeks' follow-up. There was no dose-limiting toxicity (DLT) observed to date. Grade (gr) 1/2 CRS was seen in seven of the patients. Four gr 1 and one gr 3 neurotoxicity were reported. The RR was $90 \%$ with 9/10 patients in MRD-negative CR, and 100\% MRD negativity in the 6 patients who received cell dose $\geq 3 \times 10^{6}$ CAR T cells $/ \mathrm{kg}$. The CAR T cell dose appears to be important, since 3 patients who had doses $<3 \times 10^{6} / \mathrm{kg}$ had only transient responses whereas the $4 / 6$ patients treated at the higher dose of $3 \times 10^{6} \mathrm{CAR} \mathrm{T}$ cells $/ \mathrm{kg}$ achieved durable remission with an MRD-negative CR with the longest follow-up of 4 months. This report of early data provided valuable clinical experience for dual-CAR containing $\mathrm{T}$ cell therapy of R/R ALL. With this bi-specific CAR T therapy, there has been no relapse with loss of CD19 or CD22 antigen to date. In addition, the penta-valent design of $\mathrm{CD} 22 \mathrm{ScFv}$ is of interest since this will provide further insights as to whether the new design adds additional benefit to clinical outcome.

Hossain et al. also developed a bi-cistronic CAR construct encoding CARs targeting both CD19 and CD22 simultaneously with intracellular signaling domains in-

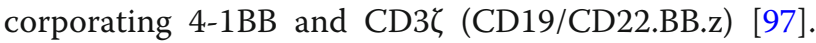
A single institution phase I dose escalation study was initiated for adult patients with R/R B-ALL or NHL after standard therapies. The primary endpoint was feasibility of manufacturing the bi-specific CAR T cells and safety at three dose levels $\left(1 \times 10^{6} \mathrm{CAR} \mathrm{T}\right.$ cells $/ \mathrm{kg}$, $3 \times 10^{6}$ CAR T cells $/ \mathrm{kg}, 1 \times 10^{7} \mathrm{CAR} \mathrm{T}$ cells $/ \mathrm{kg}$ ). Efficacy was a secondary endpoint. Six patients have been treated, all at dose level 1. All six patients developed CRS, 4 with gr 1 and 2 with gr 2, whereas CRES was observed in 3 patients. All treated patients showed persistent B cell aplasia. One of the two patients who achieved CR was an ALL patient with disease in the bone marrow/blood/CNS. This patient was MRD negative at days 28 and 60. This adult phase I trial of CD19/ 22 dual-targeted CAR $\mathrm{T}$ cells showed feasibility of manufacturing the bispecific CAR $\mathrm{T}$ cells and demonstrated preliminary efficacy. Further dose escalation is ongoing.

Schults et al. constructed a bivalent CAR targeting both CD19 and CD22 with a 4-1BB costimulatory endodomain [98]. This bivalent CAR $\mathrm{T}$ cell product was tested in pediatric patients in a phase I trial. The primary objectives are feasibility of dual-targeted CAR T cell production and safety at 3 dose levels $\left(1 \times 10^{6}, 3 \times\right.$ $10^{6}$, and $1 \times 10^{7}$ CAR T cells $/ \mathrm{kg}$ ). This initial report enrolled four pediatric patients (age 2-17) with $R / R$ precursor-B ALL, and all four patients were treated at cell dose level 1 . It appeared that all the four subjects had relatively low leukemia burden. The CARTox included 3 gr I/II CRS and 2 patients with gr I CRES. All 4 patients achieved $\mathrm{CR}$ at day 28 after the bispecific CAR $\mathrm{T}$ therapy, with $3 \mathrm{MRD}$ negative. In conclusion, the first dose level of the CD19/22-bispecific CAR T cells was well tolerated and effective.

\section{Cocktail CAR19 and CAR22 T cells}

In a recent report by Yang et al., a bi-specific CAR $T$ product was manufactured by transducing autologous $\mathrm{T}$ cells sequentially with CD19 CAR and CD22 CAR constructs [99]. The CD22 CAR also includes a ScFv of human PD-L1 in an attempt to reduce CAR $\mathrm{T}$ cell exhaustion. A phase I clinical trial was done in patients with R/R ALL. Manufacturing feasibility and toxicity were the primary end points. Nineteen patients were treated with the cocktail CAR T cells in the 2018 ASH Annual Meeting (15 at the time of abstract submission). All 19 patients had CAR T cells successfully manufactured. The enrolled patients received a median number of $1(0.9-5) \times 10^{5} \mathrm{CD} 19 \mathrm{CAR}+\mathrm{T}$ cells $/ \mathrm{kg}$ and a median number of $0.36(0.4-12) \times 10^{5} \mathrm{CD} 22 \mathrm{CAR}+\mathrm{T}$ cells $/ \mathrm{kg}$. On day 30 after CAR $\mathrm{T}$ infusion, 18/19 (94.7\%) cases achieved CR/CRi, with $94.4 \%$ of them MRD negative. There were low rates of CRS and CRES. Fourteen of the 19 patients proceeded quickly to allo-HSCT (median time 61 days). The median OS was 236 days (45-515), and PFS 234 days (14-337). There was no relapse among patients who were bridged to allo-HSCT, whereas 3 of 4 non-transplanted relapsed. All relapsed patients had CD19+/CD22+. This study raised several intriguing issues: (1) the infused number of CAR T cells were lower than those from most reports in the literature, which may have accounted for low CARTox, and high relapse rate in those patients without quick bridging to allo-HSCT. This was evidenced by the fact that the relapsed cells retained expression of CD19 and CD22 antigens. (2) The low CAR T cell doses were used in this fashion more like reinduction therapy, and the intension of the cocktail CAR T therapy was not curative and was to bridge patients quickly to allo-HSCT as a reinduction therapy. It remains unclear what the actual composition 
of the mixed CAR T cells was infused and whether the cocktail CAR $\mathrm{T}$ cells are better than the approach with adequate dose of CAR19 T cells, particularly when such low doses of CAR T cells of each type were used. It is neither clear that if the cocktail CAR T cell doses are escalated to higher and more effective levels to aim for durable remissions, whether immediate allo-HSCT is still needed.

Another group established CD19/22 dual targeting CAR $\mathrm{T}$ cells by transducing $\mathrm{T}$ cells with two separate lentiviral vectors that direct the expression of two separate CARs targeting CD19 and CD22. This approach led to a cocktail of three distinct populations of CAR T cells (anti-CD19, anti-CD22, and anti-CD19x 22). A phase I clinical trial of this cocktail was done in patients with $\mathrm{R} /$ $\mathrm{R}$ ALL [100]. Among the seven subjects (ages 1-26 years) enrolled, 4 received dose level $1\left(1 \times 10^{6}\right.$ CAR T cells $/ \mathrm{kg})$ and 3 received dose level $2\left(3 \times 10^{6}\right.$ CAR T cells $/ \mathrm{kg}$ ). Among the CD8+ CAR T cells, there were 21.6\% with CD19 CAR, 37.8\% with CD22 CAR, and $40.6 \%$ with dual CD22xCD19 CAR. Interestingly, the predominant CAR $\mathrm{T}$ cell population contained CD19 CAR, with median peak values for CD19 CAR, CD22 CAR, and CD19 $\times$ CD22 CAR T cell populations of $9.1 \%, 1.2 \%$, and $2.4 \%$, respectively. Five of the 7 subjects achieved CR, 4 of which were MRD negative. The rest of the two subjects had no evidence of CAR T cell engraftment. No DLT was observed. Only grade 1 CRS was observed in the five subjects. This study reported the distribution of a cocktail of 3 distinct populations of CAR T cells. Selective in vivo expansion of the CD19 CAR $\mathrm{T}$ cell population was discovered. It remains unclear what the mechanism is for the predominant expansion of CD19 CAR T cells over the CD22 and CD19/22 dual-targeted CAR T cell populations.

\section{Sequential administration of CAR19 and CAR22 T cells}

In addition to bi-specific CAR T cells, sequential administration of CAR19 and CAR22 T cells was also reported in $\mathrm{R} / \mathrm{R}$ ALL in a single-center and single-arm clinical trial, which was registered with Chinese Clinical Trial Registry (ChiCTR, number ChiCTR-OPN-16008526) [101]. The CAR $\mathrm{T}$ cells contained third-generation CARs. At the data cut-off on April 30, 2018, the median follow-up was 7.6 months (range 1.3 to 22.2 months) for B-ALL. CAR22 and CAR19 T cells were given sequentially in divided doses (range 1 to $4 \times 10^{6} / \mathrm{kg}$ for CAR22, and 1 to $5 \times 10^{6} / \mathrm{kg}$ for CAR19). Eighty one patients received CAR22 T cells followed by CAR19 T cells, 8 received CAR19 T cells followed by CAR22 T cells. Fifty of the enrolled R/R ALL patients were evaluable. Among them, 48 (96.0\%) achieved CR/CRi at the day 30 assessment, with 94\% MRD-negative. The PFS for all B-ALL patients was 12.0 months, and the median OS has not been reached. A total of 23 patients relapsed without antigen loss for CD19 and CD22. Forty-seven patients (92.2\%) experienced CRS with $11(21.6 \%)$ at grade 3 or higher, one of which was grade 5 . CRES was seen in 7 patients (13.7\%). This study indicated that sequential administration of third-generation CD22 and CD19 CAR T cells is feasible and safe. In the patients with R/R ALL, high MRD negativity was achieved. The kinetics of the two CAR $\mathrm{T}$ cells in vivo is still unclear, and the follow-up remains short. The durability of the remission therefore awaits longer observation.

Donor-derived allogeneic CD19-targeted CAR T cells Patients with R/R ALL relapsed after allo-HSCT have even worse prognosis, and donor leukocyte infusion can only rescue a small proportion of patients. Therefore, the efficacy and safety of donor-derived CD19-targeted CAR $\mathrm{T}$ cells for relapsed B-ALL after allo-HSCT were studied.

In a recent report at the 2018 ASH Annual Meeting, 6 patients with R/R B-ALL after allo-HSCT (5 sibling matched, 1 haplo-identical) were enrolled to receive donor-derived CAR $\mathrm{T}$ cells containing CD19 ScFv (HI-19 clone) and a 4-1BB-CD3 $\zeta$ signaling domain. There were 2 patients with full relapse and 4 patients with MRD+ disease [102]. The cell doses were 1.25$3.5 \times 10^{6} / \mathrm{kg}$ which were infused over 2 or 3 days. All 6 patients experienced mild CRS of grade $1 / 2$. There was no acute or chronic graft-versus-host disease (GVHD). With a median follow-up of 243.5 days, all the 6 patients were alive with complete donor chimerism and remained in MRD-negative remission.

Following the similar approach, two cases of CML patients with $R / R$ lymphoblastic crisis were treated with CD19-targeted donor-derived CAR T cells [103]. Both patients relapsed after allo-HSCT. One of the two patients developed grade 4 CRS and required steroids and tocilizumab. Both patients achieved molecular remission after the donor-derived CAR $\mathrm{T}$ therapy. Therefore, donor-derived CD19-directed CAR T cell treatment is a viable option for patients with R/R B-ALL who relapsed after allo-HSCT.

CD123 is a surface marker associated with AML leukemia progenitors [104]. Recent studies have shown that CD123 is highly expressed in the relapsed ALL patients [105]. Dual-targeted CD19 $\times$ CD123 CAR T cells have been shown to be effective in mouse models to eliminate CD19 antigen loss after CD19-targeted immunotherapies [106]. In a recent report, donor-derived fourth-generation CAR $\mathrm{T}$ cells targeting CD19 and CD123 respectively were administered to three R/R ALL patients who relapsed after allo-HSCT (NCT03125577) [107]. These three patients had relapsed CD19+CD123+ B-ALL after HLA-matched sibling HSCT. Among them, two patients had p190 BCR-ABL-positive ALL with 
T315I mutation. These two patients were refractory to ponatinib. All three patients had failed chemotherapy and DLI. The donor-derived $\mathrm{T}$ cells were transduced with an apoptosis-inducible, safety-engineered lentiviral CD19 or CD123 scFv CAR fused with the following

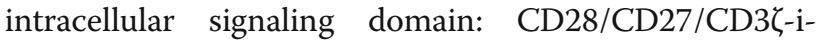
Casp9 (4SCAR19 and 4SCAR123). Therefore the CAR T cells carried a fourth-generation CAR with inducible caspases. The infused cell doses ranged 0.26-1.38 $\times 10^{6}$ cells $/ \mathrm{kg}$. All three patients achieved complete remission after CAR $\mathrm{T}$ cell infusions. The two BCR-ABL+ patients remained in complete molecular remission and disease-free for 7 months and 11 months, respectively. The third patient was in MRD-positive but morphological remission at 7 months. It was noted that the MRD+ patient received the lowest dose of CART infusion, $0.26 \times 10^{6} / \mathrm{kg}$. Regarding the safety profile of the 4SCAR design, there was no CRES; neither was there greater than grade 2 CRS and severe myelosuppression. Thus, the safety profile of the fourth-generation donor-derived CAR T cells targeting CD19 and CD123 were satisfactory, and the administration of double 4SCAR19/4SCAR123 T cells successfully rescued the high-risk relapse of R/R ALL.

Donor-derived allogeneic CAR $\mathrm{T}$ therapy has been explored in multiple trials and for multiple disease types [108]. GVHD rate remains very low in this scenario, possibly due to the low-dose CAR T cells infused. Currently, most trials of donor-derived CAR $\mathrm{T}$ cell therapy have been for R/R ALL or other R/R malignancies. It would be interesting to study low-dose donor-derived CAR $\mathrm{T}$ cells for consolidation after allo-HSCT in high-risk MRD+ diseases.

\section{CD19-targeted universal CAR T cells}

Two CD19-directed CAR T cell products have been approved for clinical use. These products are from patient-derived autologous $\mathrm{T}$ cells. These CAR $\mathrm{T}$ cells therefore are made case-by-case with a costly and lengthy production process. Currently, production failure has been reported $[49,85]$. In addition, once there is antigen loss or antigen mutation, new CAR T cells have to be made again. Therefore, universal off-the-shelf ready-to-use therapeutic CAR T cells are needed. Genome-editing technologies such as TALEN (Transcription activator-like effector nuclease) and CRISPR-Cas9 are commonly used these days to modify genes and re-engineer cells [58, 59, 109-114]. In addition to the potential for wide application of these cells to multiple recipients, these universal CAR T cells have the potential for targeting multiple antigens without re-editing and production of T cells.

Using the TALEN technology, HLA-A locus, TRAC, was knocked out to prevent TCR-mediated recognition of HLA antigens in an attempt to minimize or eliminate GVHD. To enhance lymphodepletion of recipient $\mathrm{T}$ cells, the CD52 gene was also knocked out in the off-the-shelf donor $\mathrm{T}$ cells [57]. Alemtuzumab can then be used to deplete recipient $\mathrm{T}$ cells without affecting CD52-negative donor CAR T cells. As an example of successful translation of new gene-editing technology from bench to bedside, such TALEN-edited universal CAR T cells targeting CD19, UCART19, have been applied to successfully treat two infants with R/R B-ALL [57]. The two infants of 11-month-old and 4-week old had high-risk R/R pre-B-ALL, relapsed after allo-HSCT, and both had already failed blinatumomab and a variety of rescue chemotherapies. Both patients responded to the universal CAR $\mathrm{T}$ therapy with complete remission and successfully received a second allo-HSCT.

Two international, multi-center phase I clinical trials of the off-the-shelf UCART19 cells in adults (from 16 to $<70$ years, NCT02746952, CALM study) and pediatric (from 6 months to < 18 years, NCT02808442, PALL study) patients with R/R CD19+ALL have been initiated. To be eligible, all patients must have exhausted available treatment options. The R/R ALL patients must have a morphological disease (>5\% blasts) or MRD load $\geq 1 \times 10^{-3}$. For both studies, the primary end points are safety and tolerability. In addition, in CALM study, additional primary end points include MTD and lymphodepletion regimen. The secondary end point is remission rate at day 28 . Patients with extra-medullary involvement are excluded. The lymphodepletion regimens are summarized in Table 1. The study algorithm is shown in the schema (Fig. 1). In the CALM study, 3 CAR $T$ cell dose levels were planned (Table 2). In the PALL trial, there is only one weight-based dose level which may range from 1.1 to $2.3 \times 10^{6} \mathrm{cells} / \mathrm{kg}$.

In the recent update at the 2018 ASH Annual Meeting, the data from the two trials were pooled and analyzed together [115]. In the oral presentation at the meeting, 21 patients were enrolled and received a single dose of UCART 19 cell infusion. CR/CRi was $66.7 \%$ (14/

Table 1 Lymphodepletion (LD) regimen in the universal CAR T trials PALL and CALM

\begin{tabular}{lll}
\hline LD regimen (FC or FCA) & Doses in PALL & Doses in CALM \\
\hline Fludarabine (F) & $150 \mathrm{mg} / \mathrm{m}^{2}$ & $90 \mathrm{mg} / \mathrm{m}^{2}$ \\
Cyclophosphamide (C) & $120 \mathrm{mg} / \mathrm{kg}$ & $1500 \mathrm{mg} / \mathrm{m}^{2}$ \\
Alemtuzumab (A) & $1 \mathrm{mg} / \mathrm{kg}$ (capped at $40 \mathrm{mg})$ & $1 \mathrm{mg} / \mathrm{kg}$ or $40 \mathrm{mg}$ \\
\hline
\end{tabular}

The regimen and chemotherapy doses were based on data presented at 2018 ASH Annual meeting by Benjamin et al. [115] PALL UCART19 trial in pediatric patients, NCT 02808442; CALM UCART19 trial in adult patients, NCT 02746952 


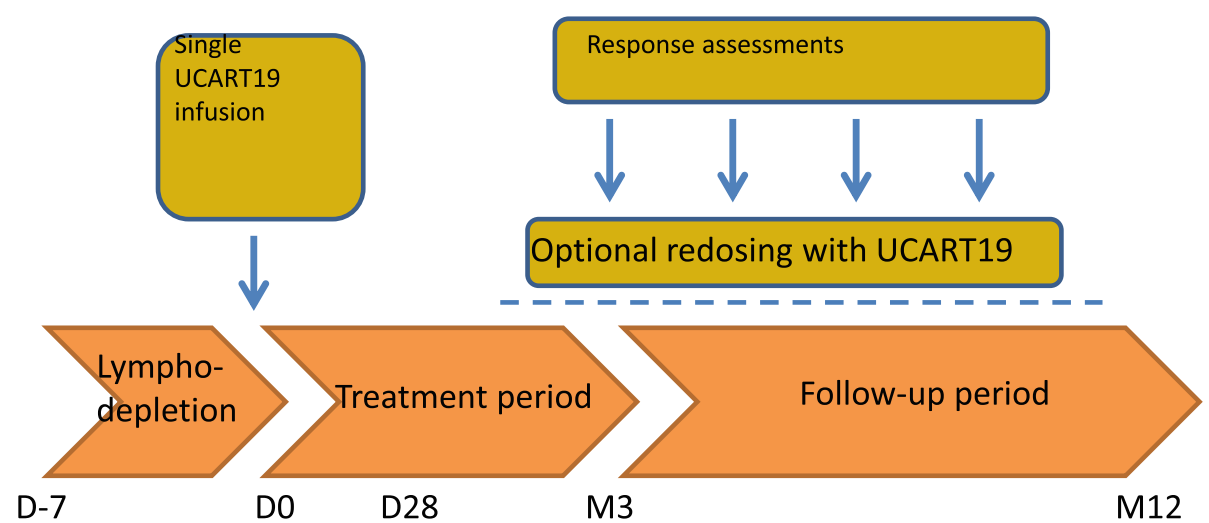

Fig. 1 The UCART19 study schema for the universal CAR T cell trials for relapsed/refractory acute lymphoid leukemia (R/R ALL). Two international multi-center studies of the universal CAR T cells, UCART19, are ongoing. PALL is the study for pediatric patients (NCT 02808442), and CALM study is for adult patients with R/R ALL (NCT 02746952). The study schema was modified from the data presented at the 2018 ASH Annual Meeting by Benjamin et al. [115]. D day, M month

21 patients). Four of the patients did not receive alemtuzumab (FC regimen) and failed to have UCART19 expansion. These four patients did not respond to the treatment. Among the rest of the 17 patients who received the alemtuzumab-containing FCA lymphodepletion regimen, 14 patients responded, CR/CRi was $82 \%$, and $71 \%(10 / 14)$ achieved MRD. Three patients who were refractory to or relapsed after initial UCART19 infusion received a second dose of UCART19 cell infusion. Two of these 3 re-dosed patients achieved MRD negativity. CRS was observed in 17 patients. Mild to moderate CRS was reported. One patient died in context of severe grade 4 CRS and neutropenic sepsis. Six patients had mild gr 1 and 2 CRES. Two patients (1 infant and 1 adult) developed grade I acute skin GVHD which was easily controlled. Some patients proceeded quickly to allo-HSCT; therefore, UCART19 persistence could not be reliably assessed beyond days $42-56$ in those patients after myeloablative conditioning therapy.

In conclusion, in this pooled analysis of the UCART19 clinical trials, only 2 of 21 patients developed grade 1 cutaneous GVHD. This unusually mild and low incidence of GVHD is truly encouraging. CRS and CRES were mostly mild. With the FCA lymphodepletion regimen, high rates of $\mathrm{CR} / \mathrm{CRi}$ and $\mathrm{MRD}$ negativity were

Table 2 The UCART19 cell doses in the universal CAR T trials PALL and CALM

\begin{tabular}{lll}
\hline PALL dose & CALM dose levels & \\
\hline weight-based dose & DL1:6 $\times 10^{6}$ & $\approx 1 \times 10^{5} \mathrm{cells} / \mathrm{kg}$ \\
$\left(1.1\right.$ to $2.3 \times 10^{6}$ cells $\left./ \mathrm{kg}\right)$ & DL2:6 or $8 \times 10^{7}$ & $\approx 1 \times 10^{6} \mathrm{cells} / \mathrm{kg}$ \\
& DL3:1.8 or $2.4 \times 10^{8}$ & $\approx 3 \times 10^{6} \mathrm{cells} / \mathrm{kg}$ \\
\hline
\end{tabular}

The cell doses were based on data presented at 2018 ASH Annual meeting by Benjamin et al. [115]

DL dose level; PALL UCART19 trial in pediatric patients, NCT 02808442; CALM UCART19 trial in adult patients, NCT 02746952 achieved after UCART19 infusion in these heavily-pretreated patients who would otherwise have no treatment options. These international multi-center off-the-shelf universal UCART19 trials are currently ongoing. More clinical trials of CRISPR/Cas9 gene-edited universal CAR T cells are underway (NCT03166878, NCT03229876). Both of these universal CAR T trials were for CD19+ ALL. More updates are expected to come in the near future.

\section{Conclusion}

Two autologous CAR19 $\mathrm{T}$ cell products have been approved. Antigen loss remains a major mechanism of disease relapse. Dual-target CAR T cells against CD19 and CD22 are in multiple clinical trials. The dosage and kinetics of the dual-target and cocktail CAR T cells remain to be determined. It would be interesting to compare the outcome from dual-CAR $\mathrm{T}$ therapy with that from single-CAR T therapy. Donor-derived allogeneic CAR T cells are being studied to combat relapsed malignancies after allo-HSCT. UCART19 universal CAR T cells have been shown in early international multi-center clinical trials to be safe with exceptionally low GVHD rate. This off-the-shelf third-party universal CAR $\mathrm{T}$ cell product bears the hope and burden of proof for large-scale clinical application of CAR T cell immunotherapy.

\section{Abbreviations}

ALL: Acute lymphoid leukemia; CAR: Chimeric antigen receptor; CRISPR/ Cas9: Clustered regularly interspaced short palindromic repeat (CRISPR)CRISPR-associated 9 (Cas9); TALEN: Transcription activator-like effector nuclease

\section{Acknowledgements}

$\mathrm{DL}$ is a professor of medicine in the Department of Medicine, New York Medical College and Westchester Medical Center, Valhalla, NY, USA. 


\section{Funding}

The study is partly supported by the Affiliated Caner Hospital of Zhengzhou University, Zhengzhou, and by the National Natural Science Foundation of China (NSFC grant no. 81470287, YPS).

\section{Availability of data and materials}

The material supporting the conclusion of this review has been included within the article.

\section{Authors' contributions}

DL designed the study and drafted the manuscript. JZ prepared the figure and tables. All authors participated in the revision of the manuscript. All authors read and approved the final manuscript.

\section{Ethics approval and consent to participate}

This is not applicable for this review.

\section{Consent for publication}

This is not applicable for this review.

\section{Competing interests}

The authors declare that they have no competing interests.

\section{Publisher's Note}

Springer Nature remains neutral with regard to jurisdictional claims in published maps and institutional affiliations.

Received: 15 December 2018 Accepted: 7 February 2019 Published online: 14 February 2019

\section{References}

1. Pui C-H, Campana D, Pei D, Bowman WP, Sandlund JT, Kaste SC, Ribeiro RC, Rubnitz JE, Raimondi SC, Onciu M, Coustan-Smith E, Kun LE, Jeha S, Cheng C, Howard SC, Simmons V, Bayles A, Metzger ML, Boyett JM, Leung W, Handgretinger R, Downing JR, Evans WE, Relling MV. Treating childhood acute lymphoblastic leukemia without cranial irradiation. N Engl J Med. 2009;360(26):2730-41.

2. Schrappe M, Hunger SP, Pui C-H, Saha V, Gaynon PS, Baruchel A, Conter V, Otten J, Ohara A, Versluys AB, Escherich G, Heyman M, Silverman LB, Horibe K, Mann G, Camitta BM, Harbott J, Riehm H, Richards S, Devidas M, Zimmermann M. Outcomes after induction failure in childhood acute lymphoblastic leukemia. N Engl J Med. 2012;366(15):1371-81.

3. Hunger SP, Mullighan CG. Acute lymphoblastic leukemia in children. N Engl J Med. 2015;373(16):1541-52.

4. Curran E, Stock W. How I treat acute lymphoblastic leukemia in older adolescents and young adults. Blood. 2015;125(24):3702-10.

5. Frey NV, Luger SM. How I treat adults with relapsed or refractory Philadelphia chromosome-negative acute lymphoblastic leukemia. Blood. 2015;126(5):589-96.

6. Litzow MR, Ferrando AA. How I treat T-cell acute lymphoblastic leukemia in adults. Blood. 2015:126(7):833-41.

7. Terwilliger T, Abdul-Hay M. Acute lymphoblastic leukemia: a comprehensive review and 2017 update. Blood Cancer J. 2017;7:e577.

8. Goekbuget N, Hoelzer D. Treatment of adult acute lymphoblastic leukemia. Semin Hematol. 2009;46(1):64-75.

9. Gökbuget N, Stanze D, Beck J, Diedrich H, Horst H-A, Hüttmann A, Kobbe G, Kreuzer K-A, Leimer L, Reichle A, Schaich M, Schwartz S, Serve H, Starck M, Stelljes M, Stuhlmann R, Viardot A, Wendelin K, Freund M, Hoelzer D. Outcome of relapsed adult lymphoblastic leukemia depends on response to salvage chemotherapy, prognostic factors, and performance of stem cell transplantation. Blood. 2012;120(10):2032-41.

10. Rossari F, Minutolo F, Orciuolo E. Past, present, and future of Bcr-Abl inhibitors: from chemical development to clinical efficacy. J Hematol Oncol. 2018;11(1):84.

11. Roberts KG, Li Y, Payne-Turner D, Harvey RC, Yang Y-L, Pei D, McCastlain K, Ding L, Lu C, Song G, Ma J, Becksfort J, Rusch M, Chen S-C, Easton J, Cheng J, Boggs K, Santiago-Morales N, lacobucci I, Fulton RS, Wen J, Valentine M, Cheng C, Paugh SW, Devidas M, Chen I-M, Reshmi S, Smith A, Hedlund E, Gupta P, et al. Targetable kinase-activating lesions in Ph-like acute lymphoblastic leukemia. N Engl J Med. 2014;371(11):1005-15.
12. Ling $Y$, Xie Q, Zhang Z, Zhang $H$. Protein kinase inhibitors for acute eukemia. Biomarker Res. 2018:6(1):8.

13. Cortes JE, Apperley JF, DeAngelo DJ, Deininger MW, Kota VK, Rousselot P, Gambacorti-Passerini C. Management of adverse events associated with bosutinib treatment of chronic-phase chronic myeloid leukemia: expert panel review. J Hematol Oncol. 2018:11(1):143.

14. Cortes JE, Gambacorti-Passerini C, Deininger MW, Mauro MJ, Chuah C, Kim DW, Dyagil I, Glushko N, Milojkovic D, le Coutre P, Garcia-Gutierrez V, Reilly $L$, Jeynes-Ellis A, Leip E, Bardy-Bouxin N, Hochhaus A, Brummendorf TH. Bosutinib versus Imatinib for newly diagnosed chronic myeloid leukemia: results from the randomized BFORE trial. J Clin Oncol. 2018;36(3):231-7.

15. Sasaki K, Jabbour EJ, Ravandi F, Short NJ, Thomas DA, Garcia-Manero G, Daver NG, Kadia TM, Konopleva MY, Jain N, Issa GC, Jeanis V, Moore HG, Garris RS, Pemmaraju N, Cortes JE, O'Brien SM, Kantarjian HM. Hyper-CVAD plus ponatinib versus hyper-CVAD plus dasatinib as frontline therapy for patients with Philadelphia chromosome-positive acute lymphoblastic leukemia: a propensity score analysis. Cancer. 2016:122(23):3650-6.

16. Jabbour E, Kantarjian H, Ravandi F, Thomas D, Huang X, Faderl S, Pemmaraju N, Daver N, Garcia-Manero G, Sasaki K, Cortes J, Garris R, Yin CC, Khoury JD, Jorgensen J, Estrov Z, Bohannan Z, Konopleva M, Kadia T, Jain N, DiNardo C, Wierda W, Jeanis V, O'Brien S. Combination of hyper-CVAD with ponatinib as first-line therapy for patients with Philadelphia chromosomepositive acute lymphoblastic leukaemia: a single-centre, phase 2 study. Lancet Oncol. 2015:16(15):1547-55.

17. Jabbour E, Short NJ, Ravandi F, Huang X, Daver N, DiNardo CD, Konopleva M, Pemmaraju N, Wierda W, Garcia-Manero G, Sasaki K, Cortes J, Garris R, Khoury JD, Jorgensen J, Jain N, Alvarez J, O'Brien S, Kantarjian H. Combination of hyper-CVAD with ponatinib as first-line therapy for patients with Philadelphia chromosome-positive acute lymphoblastic leukaemia: long-term follow-up of a single-centre, phase 2 study. Lancet Haematol. 2018;5(12):e618-27.

18. Maury $\mathrm{S}$, Chevret $\mathrm{S}$, Thomas $\mathrm{X}$, Heim $\mathrm{D}$, Leguay $\mathrm{T}$, Huguet $\mathrm{F}$, Chevallier $\mathrm{P}$, Hunault M, Boissel N, Escoffre-Barbe M, Hess U, Vey N, Pignon J-M, Braun T, Marolleau J-P, Cahn J-Y, Chalandon Y, Lhéritier V, Beldjord K, Béné MC, Ifrah $\mathrm{N}$, Dombret H. Rituximab in B-lineage adult acute lymphoblastic leukemia. N Engl J Med. 2016:375(11):1044-53.

19. Ribrag V, Koscielny S, Bosq J, Leguay T, Casasnovas O, Fornecker L-M, Recher C, Ghesquieres H, Morschhauser F, Girault S, Gouill SL, Ojeda-Uribe M, Mariette C, Cornillon J, Cartron G, Verge V, Chassagne-Clément C, Dombret H, Coiffier B, Lamy T, Tilly H, Salles G. Rituximab and dose-dense chemotherapy for adults with Burkitt's lymphoma: a randomised, controlled open-label, phase 3 trial. Lancet. 2016;387(10036):2402-11.

20. Kantarjian H, Stein A, Gokbuget N, Fielding AK, Schuh AC, Ribera JM, Wei A, Dombret H, Foa R, Bassan R, Arslan O, Sanz MA, Bergeron J, Demirkan F, Lech-Maranda E, Rambaldi A, Thomas X, Horst HA, Bruggemann M, Klapper W, Wood BL, Fleishman A, Nagorsen D, Holland C, Zimmerman Z, Topp MS. Blinatumomab versus chemotherapy for advanced acute lymphoblastic leukemia. N Engl J Med. 2017;376(9):836-47.

21. Topp MS, Kufer $P$, Gokbuget $N$, Goebeler M, Klinger M, Neumann S, Horst HA, Raff T, Viardot A, Schmid M, Stelljes M, Schaich M, Degenhard E, KohneVolland R, Bruggemann M, Ottmann O, Pfeifer $\mathrm{H}$, Burmeister T, Nagorsen D, Schmidt M, Lutterbuese R, Reinhardt C, Baeuerle PA, Kneba M, Einsele H, Riethmuller G, Hoelzer D, Zugmaier G, Bargou RC. Targeted therapy with the T-cell-engaging antibody blinatumomab of chemotherapy-refractory minimal residual disease in B-lineage acute lymphoblastic leukemia patients results in high response rate and prolonged leukemia-free survival. J Clin Oncol. 2011;29(18):2493-8.

22. Topp MS, Gokbuget N, Zugmaier G, Degenhard E, Goebeler ME, Klinger M, Neumann SA, Horst HA, Raff T, Viardot A, Stelljes M, Schaich M, KohneVolland R, Bruggemann M, Ottmann OG, Burmeister T, Baeuerle PA, Nagorsen D, Schmidt M, Einsele H, Riethmuller G, Kneba M, Hoelzer D, Kufer $P$, Bargou RC. Long-term follow-up of hematologic relapse-free survival in a phase 2 study of blinatumomab in patients with MRD in B-lineage ALL. Blood. 2012;120(26):5185-7.

23. Topp MS, Gokbuget N, Stein AS, Zugmaier G, O'Brien S, Bargou RC, Dombret H, Fielding AK, Heffner L, Larson RA, Neumann S, Foa R, Litzow M, Ribera JM, Rambaldi A, Schiller G, Bruggemann M, Horst HA, Holland C, Jia C, Maniar T, Huber B, Nagorsen D, Forman SJ, Kantarjian HM. Safety and activity of blinatumomab for adult patients with relapsed or refractory Bprecursor acute lymphoblastic leukaemia: a multicentre, single-arm, phase 2 study. Lancet Oncol. 2014;16(1):57-66. 
24. Topp MS, Gokbuget N, Zugmaier G, Klappers P, Stelljes M, Neumann S, Viardot A, Marks R, Diedrich H, Faul C, Reichle A, Horst HA, Bruggemann M, Wessiepe D, Holland C, Alekar S, Mergen N, Einsele H, Hoelzer D, Bargou RC. Phase II trial of the anti-CD19 bispecific T cell-engager blinatumomab shows hematologic and molecular remissions in patients with relapsed or refractory B-precursor acute lymphoblastic leukemia. J Clin Oncol. 2014; 32(36):4134-40.

25. Zhang $X$, Yang $Y$, Fan D, Xiong D. The development of bispecific antibodies and their applications in tumor immune escape. Exp Hematol Oncol. 2017;6(1):12.

26. Nägele V, Kratzer A, Zugmaier G, Holland C, Hijazi Y, Topp MS, Gökbuget N, Baeuerle PA, Kufer P, Wolf A, Klinger M. Changes in clinical laboratory parameters and pharmacodynamic markers in response to blinatumomab treatment of patients with relapsed/refractory ALL. Exp Hematol Oncol. 2017;6(1):14

27. Richard-Carpentier G, Kantarjian HM, Short NJ, Ravandi F, Ferrajoli A Schroeder HM, Khouri M, Garcia-Manero G, Montalban Bravo G, Cortes JE, Jain N, Konopleva MY, Takahashi K, Sasaki K, Garris RE, Jabbour EJ. A phase II study of the hyper-CVAD regimen in sequential combination with blinatumomab as frontline therapy for adults with B-cell acute lymphoblastic leukemia (B-ALL). Blood. 2018;132(Suppl 1):32.

28. Kantarjian HM, DeAngelo DJ, Stelljes M, Martinelli G, Liedtke M, Stock W, Gokbuget N, O'Brien S, Wang K, Wang T, Paccagnella ML, Sleight B, Vandendries E, Advani AS. Inotuzumab ozogamicin versus standard therapy for acute lymphoblastic leukemia. N Engl J Med. 2016;375(8):740-53.

29. Sasaki K, Kantarjian HM, Ravandi F, Short NJ, Kebriaei P, Huang X, Rytting ME, Jain N, Konopleva MY, Garcia-Manero G, Champlin RE, Kadia TM, Cortes JE, Estrov ZE, Takahashi K, Mace M, Khouri M, Nasnas P, Jacob J, Garris RE, Jabbour EJ. Sequential combination of low-intensity chemotherapy (Minihyper-CVD) plus inotuzumab ozogamicin with or without blinatumomab in patients with relapsed/refractory philadelphia chromosome-negative acute lymphoblastic leukemia (ALL): a phase 2 trial. Blood. 2018;132(Suppl 1):553.

30. Short NJ, Jabbour EJ, Ravandi F, Huang X, Jain N, Sasaki K, Pemmaraju N, Daver NG, Khoury JD, Jorgensen JL, Alvarado Y, Konopleva MY, GarciaManero G, Kadia TM, Yilmaz M, Borthakur G, Burger JA, Kornblau SM, Wierda WG, CD DN, Ferrajoli A, Nasnas P, Jacob J, Garris RE, Brien SM, Kantarjian HM. Chemoimmunotherapy with inotuzumab ozogamicin combined with mini-hyper-CVD, with or without blinatumomab, for newly diagnosed older patients with Philadelphia chromosome-negative acute lymphoblastic leukemia: results from a phase II study. Blood. 2018;132(Suppl 1):36.

31. Jabbour E, Pui CH, Kantarjian H. Progress and innovations in the management of adult acute lymphoblastic leukemia. JAMA Oncol. 2018. 4(10):1413-20.

32. Jabbour E, Ravandi F, Kebriaei P, Huang X, Short NJ, Thomas D, Sasaki K, Rytting M, Jain N, Konopleva M, Garcia-Manero G, Champlin R, Marin D, Kadia T, Cortes J, Estrov Z, Takahashi K, Patel Y, Khouri MR, Jacob J, Garris R, O'Brien S, Kantarjian H. Salvage chemoimmunotherapy with inotuzumab ozogamicin combined with mini-hyper-CVD for patients with relapsed or refractory philadelphia chromosome-negative acute lymphoblastic leukemia: a phase 2 clinical trial. JAMA Oncol. 2018;4(2):230-4.

33. Jabbour E, Sasaki K, Ravandi F, Huang X, Short NJ, Khouri M, Kebriaei P, Burger J, Khoury J, Jorgensen J, Jain N, Konopleva M, Garcia-Manero G, Kadia T, Cortes J, Jacob J, Montalbano K, Garris R, O'Brien S, Kantarjian HM. Chemoimmunotherapy with inotuzumab ozogamicin combined with minihyper-CVD, with or without blinatumomab, is highly effective in patients with Philadelphia chromosome-negative acute lymphoblastic leukemia in first salvage. Cancer. 2018;124(20):4044-55

34. Jabbour EJ, DeAngelo DJ, Stelljes M, Stock W, Liedtke M, Gokbuget N, O'Brien S, Wang T, Paccagnella ML, Sleight B, Vandendries E, Advani AS, Kantarjian HM. Efficacy and safety analysis by age cohort of inotuzumab ozogamicin in patients with relapsed or refractory acute lymphoblastic leukemia enrolled in INO-VATE. Cancer. 2018;124(8):1722-32.

35. Kantarjian $H$, Thomas D, Jorgensen J, Jabbour E, Kebriaei P, Rytting M, York S, Ravandi F, Kwari M, Faderl S, Rios MB, Cortes J, Fayad L, Tarnai R, Wang SA, Champlin R, Advani A, O'Brien S. Inotuzumab ozogamicin, an anti-CD22calecheamicin conjugate, for refractory and relapsed acute lymphocytic leukaemia: a phase 2 study. Lancet Oncol. 2012;13(4):403-11.

36. Kantarjian $H$, Thomas $D$, Jorgensen J, Kebriaei $P$, Jabbour E, Rytting M, York S, Ravandi F, Garris R, Kwari M, Faderl S, Cortes J, Champlin R, O'Brien S. Results of inotuzumab ozogamicin, a CD22 monoclonal antibody, in refractory and relapsed acute lymphocytic leukemia. Cancer. 2013;119(15): 2728-36.
37. Kantarjian $\mathrm{H}$, Jabbour $\mathrm{E}$. Incorporating immunotherapy into the treatment strategies of B-cell adult acute lymphoblastic leukemia: the role of blinatumomab and inotuzumab ozogamicin. Am Soc Clin Oncol Educ Book. 2018;38:574-8.

38. Kantariian $H$, Ravandi F, Short NJ, Huang $X$, Jain N, Sasaki K, Daver N, Pemmaraju N, Khoury JD, Jorgensen J, Alvarado Y, Konopleva M, GarciaManero G, Kadia T, Yilmaz M, Bortakhur G, Burger J, Kornblau S, Wierda W, DiNardo C, Ferrajoli A, Jacob J, Garris R, O'Brien S, Jabbour E. Inotuzumab ozogamicin in combination with low-intensity chemotherapy for older patients with Philadelphia chromosome-negative acute lymphoblastic leukaemia: a single-arm, phase 2 study. Lancet Oncol. 2018;19(2):240-8.

39. Fan M, Li M, Gao L, Geng S, Wang J, Wang Y, Yan Z, Yu L. Chimeric antigen receptors for adoptive $T$ cell therapy in acute myeloid leukemia. J Hematol Oncol. 2017:10(1):151.

40. June $\mathrm{CH}, \mathrm{O}$ 'Connor RS, Kawalekar OU, Ghassemi S, Milone MC. CAR T cell immunotherapy for human cancer. Science. 2018;359(6382):1361-5.

41. June $\mathrm{CH}$, Sadelain M. Chimeric antigen receptor therapy. N Engl J Med. 2018;379(1):64-73

42. Sadelain M, Brentjens R, Riviere I, Park J. CD19 CAR therapy for acute lymphoblastic leukemia. Am Soc Clin Oncol Educ Book. 2015;35:e360-3.

43. Sadelain M, Rivière I, Riddell S. Therapeutic T cell engineering. Nature. 2017; 545:423.

44. Wang Z, Wu Z, Liu Y, Han W. New development in CAR-T cell therapy. J Hematol Oncol. 2017;10(1):53.

45. Zhang C, Liu J, Zhong JF, Zhang X. Engineering CAR-T cells. Biomarker Res. 2017;5(1):22.

46. Wei G, Ding L, Wang J, Hu Y, Huang H. Advances of CD19-directed chimeric antigen receptor-modified $T$ cells in refractory/relapsed acute lymphoblastic leukemia. Exp Hematol Oncol. 2017;6(1):10.

47. Zhu YM, Wu Z, Tan YP, Du YY, Liu Z, Ou RM, Liu S, Pu CF, Jiang J, Wang JP, Xiao L, Zhang Q. Anti-CD19 chimeric antigen receptor T-cell therapy for adult Philadelphia chromosome-positive acute lymphoblastic leukemia: two case reports. Medicine (Baltimore). 2016;95(51):e5676.

48. Maude SL, Frey N, Shaw PA, Aplenc R, Barrett DM, Bunin NJ, Chew A, Gonzalez VE, Zheng Z, Lacey SF, Mahnke YD, Melenhorst JJ, Rheingold SR, Shen A, Teachey DT, Levine BL, June CH, Porter DL, Grupp SA. Chimeric antigen receptor T cells for sustained remissions in leukemia. N Engl J Med. 2014;371(16):1507-17.

49. Maude SL, Laetsch TW, Buechner J, Rives S, Boyer M, Bittencourt H, Bader P, Verneris MR, Stefanski HE, Myers GD, Qayed M, De Moerloose B, Hiramatsu $\mathrm{H}$, Schlis K, Davis KL, Martin PL, Nemecek ER, Yanik GA, Peters C, Baruchel A, Boissel N, Mechinaud F, Balduzzi A, Krueger J, June CH, Levine BL, Wood P, Taran T, Leung M, Mueller KT, et al. Tisagenlecleucel in children and young adults with B-cell lymphoblastic leukemia. N Engl J Med. 2018;378(5):439-48.

50. Neelapu SS, Locke FL, Bartlett NL, Lekakis L, Miklos DB, Jacobson CA, Braunschweig I, Oluwole OO, Siddiqi T, Lin Y, Timmerman JM, Stiff PJ, Friedberg JW, Flinn IW, Goy A, Hill BT, Smith MR, Deol A, Farooq U, McSweeney P, Munoz J, Avivi I, Castro JE, Westin JR, Chavez JC, Ghobadi A, Komanduri KV, Levy R, Jacobsen ED, Witzig TE, et al. Axicabtagene ciloleucel CAR T-cell therapy in refractory large B-cell lymphoma. N Engl J Med. 2017;377(26):2531-44.

51. Wang J, Hu Y, Huang $\mathrm{H}$. Current development of chimeric antigen receptor T-cell therapy. Stem Cell Investigation. 2018;5:44

52. Georgiadis C, Preece R, Nickolay L, Etuk A, Petrova A, Ladon D, Danyi A, Humphryes-Kirilov N, Ajetunmobi A, Kim D, Kim JS, Qasim W. Long terminal repeat CRISPR-CAR-coupled "universal" $T$ cells mediate potent anti-leukemic effects. Mol Ther. 2018;26(5):1215-27.

53. Urnov FD. A path to efficient gene editing. Nat Med. 2018;24(7):899-900.

54. Urnov FD, Rebar EJ, Holmes MC, Zhang HS, Gregory PD. Genome editing with engineered zinc finger nucleases. Nat Rev Genet. 2010;11(9):636-46.

55. Orlando SJ, Santiago Y, DeKelver RC, Freyvert $Y$, Boydston EA, Moehle EA, Choi VM, Gopalan SM, Lou JF, Li J, Miller JC, Holmes MC, Gregory PD, Urnov $F D$, Cost GJ. Zinc-finger nuclease-driven targeted integration into mammalian genomes using donors with limited chromosomal homology. Nucleic Acids Res. 2010;38(15):e152.

56. Ren J, Zhao Y. Advancing chimeric antigen receptor T cell therapy with CRISPR/Cas9. Protein Cell. 2017:8(9):634-43.

57. Qasim W, Zhan H, Samarasinghe S, Adams S, Amrolia P, Stafford S, Butler K Rivat C, Wright G, Somana K, Ghorashian S, Pinner D, Ahsan G, Gilmour K, Lucchini G, Inglott S, Mifsud W, Chiesa R, Peggs KS, Chan L, Farzeneh F, Thrasher AJ, Vora A, Pule M, Veys P. Molecular remission of infant B-ALL after infusion of universal TALEN gene-edited CAR T cells. Sci Transl Med. 2017; 9(374). https:/doi.org/10.1126/scitranslmed.aaj2013. 
58. Dunbar CE, High KA, Joung JK, Kohn DB, Ozawa K, Sadelain M. Gene therapy comes of age. Science. 2018;359(6372). https://doi.org/10.1126/ science.aan4672

59. Zhao J, Lin Q, Song Y, Liu D. Universal CARs, universal T cells, and universal CAR T cells. J Hematol Oncol. 2018;11(1):132.

60. Chen YY. Increasing T cell versatility with SUPRA CARs. Cell. 2018;173(6): 1316-7

61. Cho JH, Collins JJ, Wong WW. Universal chimeric antigen receptors for multiplexed and logical control of T cell responses. Cell. 2018;173(6):1426-38.

62. Ma JS, Kim JY, Kazane SA, Choi SH, Yun HY, Kim MS, Rodgers DT, Pugh HM, Singer O, Sun SB, Fonslow BR, Kochenderfer JN, Wright TM, Schultz PG, Young TS, Kim CH, Cao Y. Versatile strategy for controlling the specificity and activity of engineered T cells. Proc Natl Acad Sci U S A. 2016;113(4): E450-8.

63. Barrett DM, Singh N, Porter DL, Grupp SA, June $\mathrm{CH}$. Chimeric antigen receptor therapy for cancer. Annu Rev Med. 2014;65:333-47.

64. Grupp SA, Kalos M, Barrett D, Aplenc R, Porter DL, Rheingold SR, Teachey DT, Chew A, Hauck B, Wright JF, Milone MC, Levine BL, June CH. Chimeric antigen receptor-modified T cells for acute lymphoid leukemia. N Engl J Med. 2013;368(16):1509-18.

65. Ribas A. Releasing the brakes on cancer immunotherapy. N Engl J Med. 2015;373(16):1490-2

66. Jackson HJ, Rafiq S, Brentjens RJ. Driving CAR T-cells forward. Nat Rev Clin Oncol. 2016;13(6):370-83.

67. Rosenbaum L. Tragedy, perseverance, and chance - the story of CAR-T therapy. N Engl J Med. 2017;377:1313-5.

68. Davila ML, Brentjens R, Wang X, Riviere I, Sadelain M. How do CARs work?: early insights from recent clinical studies targeting CD19. Oncoimmunology. 2012;1(9):1577-83.

69. Ping Y, Liu C, Zhang Y. T-cell receptor-engineered T cells for cancer treatment: current status and future directions. Protein Cell. 2018;9(3):254-66.

70. Liu B, Song Y, Liu D. Clinical trials of CAR-T cells in China. J Hematol Oncol. 2017;10(1):166.

71. Zhang L-N, Song Y, Liu D. CD19 CAR-T cell therapy for relapsed/refractory acute lymphoblastic leukemia: factors affecting toxicities and long-term efficacies. J Hematol Oncol. 2018;11(1):41.

72. Qin L, Lai $Y$, Zhao R, Wei X, Weng J, Lai P, Li B, Lin S, Wang S, Wu Q, Liang Q, Li Y, Zhang X, Wu Y, Liu P, Yao Y, Pei D, Du X, Li P. Incorporation of a hinge domain improves the expansion of chimeric antigen receptor $T$ cells. J Hematol Oncol. 2017;10(1):68

73. Qin L, Zhao R, Li P. Incorporation of functional elements enhances the antitumor capacity of CAR T cells. Exp Hematol Oncol. 2017;6(1):28.

74. Porter DL, Hwang WT, Frey NV, Lacey SF, Shaw PA, Loren AW, Bagg A, Marcucci KT, Shen A, Gonzalez V, Ambrose D, Grupp SA, Chew A, Zheng Z, Milone MC, Levine BL, Melenhorst JJ, June $\mathrm{CH}$. Chimeric antigen receptor T cells persist and induce sustained remissions in relapsed refractory chronic lymphocytic leukemia. Sci Transl Med. 2015;7(303):303ra139.

75. Porter DL, Kalos M, Zheng Z, Levine B, June C. Chimeric antigen receptor therapy for B-cell malignancies. J Cancer. 2011;2:331-2.

76. Porter DL, Levine BL, Kalos M, Bagg A, June $\mathrm{CH}$. Chimeric antigen receptormodified T cells in chronic lymphoid leukemia. N Engl J Med. 2011;365(8): 725-33

77. Locke FL, Neelapu SS, Bartlett NL, Siddiqi T, Chavez JC, Hosing CM, Ghobadi A, Budde LE, Bot A, Rossi JM, Jiang Y, Xue AX, Elias M, Aycock J, Wiezorek J, Go WY. Phase 1 results of ZUMA-1: a multicenter study of KTE-C19 antiCD19 CAR T cell therapy in refractory aggressive lymphoma. Mol Ther. 2017; 25(1):285-95.

78. Wang Y, Zhang WY, Han QW, Liu Y, Dai HR, Guo YL, Bo J, Fan H, Zhang Y, Zhang YJ, Chen MX, Feng KC, Wang QS, Fu XB, Han WD. Effective response and delayed toxicities of refractory advanced diffuse large B-cell lymphoma treated by CD20-directed chimeric antigen receptor-modified T cells. Clin Immunol. 2014;155(2):160-75.

79. Li Z, Song W, Rubinstein M, Liu D. Recent updates in cancer immunotherapy: a comprehensive review and perspective of the 2018 China Cancer Immunotherapy Workshop in Beijing. J Hematol Oncol. 2018; 11(1):142.

80. Liu D, Zhao J. Cytokine release syndrome: grading, modeling, and new therapy. J Hematol Oncol. 2018;11(1):121.

81. Porter D, Frey N, Wood PA, Weng Y, Grupp SA. Grading of cytokine release syndrome associated with the CAR T cell therapy tisagenlecleucel. J Hematol Oncol. 2018;11(1):35.
82. Giavridis T, van der Stegen SJC, Eyquem J, Hamieh M, Piersigilli A, Sadelain M. CAR T cell-induced cytokine release syndrome is mediated by macrophages and abated by IL-1 blockade. Nat Med. 2018;24(6):731-8.

83. Norelli M, Camisa B, Barbiera G, Falcone L, Purevdorj A, Genua M, Sanvito F, Ponzoni M, Doglioni C, Cristofori P, Traversari C, Bordignon C, Ciceri F, Ostuni R, Bonini C, Casucci M, Bondanza A. Monocyte-derived IL-1 and IL-6 are differentially required for cytokine-release syndrome and neurotoxicity due to CAR T cells. Nat Med. 2018;24(6):739-48.

84. Wang Z, Han W. Biomarkers of cytokine release syndrome and neurotoxicity related to CAR-T cell therapy. Biomarker Research. 2018;6(1):4

85. Park JH, Rivière I, Gonen M, Wang X, Sénéchal B, Curran KJ, Sauter C, Wang Y, Santomasso B, Mead E, Roshal M, Maslak P, Davila M, Brentjens RJ, Sadelain M. Long-Term Follow-up of CD19 CAR Therapy in Acute Lymphoblastic Leukemia. N Engl J Med. 2018;378:449-59.

86. Cordeiro A, Bezerra ED, Hill JA, Turtle CJ, Maloney DG, Bar M. Late effects of CD19-targeted CAR-T cell therapy. Blood. 2018;132(Suppl 1):223.

87. Zhang X, Lu XA, Yang J, LV F, Xiong M, Zhang J, Zhou X, He T, Lu P. Efficacy and safety of CD19 chimeric antigen receptor (CAR) T cell therapy for B-cell acute lymphocytic leukemia (B-cell ALL) in a large cohort including patients with extramedullary disease(EMD), high leukemia burden, BCR-ABL (+) mutation, TP53 mutation, and post-transplant relapse. Blood. 2018;132(Suppl 1):280.

88. Zhao Y, Zhang J, Liu D, Xiong M, Wei Z, Sun R, Zhou J, Lu Y, Cao X, Yang J, Zhang X, Wang H, Liu H, Lu P, Lu D. CD19-CAR-T therapy followed by allogeneic hematopoietic stem cell transplantation in refractory/relapsed and High risk B-cell acute lymphoblastic leukemia. Blood. 2018;132(Suppl 1):2660.

89. Stamenkovic I, Seed B. The B-cell antigen CD22 mediates monocyte and erythrocyte adhesion. Nature. 1990;345(6270):74-7.

90. Wilson GL, Fox CH, Fauci AS, Kehrl JH. cDNA cloning of the B cell membrane protein CD22: a mediator of B-B cell interactions. J Exp Med. 1991;173(1):137-46.

91. Ereno-Orbea J, Sicard T, Cui H, Mazhab-Jafari MT, Benlekbir S, Guarne A, Rubinstein JL, Julien JP. Molecular basis of human CD22 function and therapeutic targeting. Nat Commun. 2017:8(1):764.

92. Clark EA, Giltiay NV. CD22: a regulator of innate and adaptive B cell responses and autoimmunity. Front Immunol. 2018;9:2235.

93. Rosenthal J, Naqvi AS, Luo M, Wertheim G, Paessler M, Thomas-Tikhonenko A, Rheingold SR, Pillai V. Heterogeneity of surface CD19 and CD22 expression in B lymphoblastic leukemia. Am J Hematol. 2018;93(11):E352-5.

94. Fry TJ, Shah NN, Orentas RJ, Stetler-Stevenson M, Yuan CM, Ramakrishna S, Wolters P, Martin S, Delbrook C, Yates B, Shalabi H, Fountaine TJ, Shern JF, Majzner RG, Stroncek DF, Sabatino M, Feng $Y$, Dimitrov DS, Zhang L, Nguyen S, Qin H, Dropulic B, Lee DW, Mackall CL. CD22-targeted CAR T cells induce remission in B-ALL that is naive or resistant to CD19-targeted CAR immunotherapy. Nat Med. 2018;24(1):20-8.

95. Yates B, Shalabi H, Salem D, Delbrook C, Yuan CM, Stetler-Stevenson M, Fry TJ, Shah NN. Sequential CD22 targeting impacts CD22 CAR-T cell response. Blood. 2018;132(Suppl 1):282.

96. Amrolia PJ, Wynn R, Hough R, Vora A, Bonney D, Veys P, Rao K, Chiesa R, AlHajj M, Cordoba SP, Onuoha S, Kotsopoulou E, Khokhar NZ, Pule M, Peddareddigari VGR. Simultaneous targeting of CD19 and CD22: phase I study of AUTO3, a bicistronic chimeric antigen receptor (CAR) T-cell therapy, in pediatric patients with relapsed/refractory B-cell acute lymphoblastic leukemia (r/r B-ALL): Amelia Study. Blood. 2018;132(Suppl 1):279.

97. Hossain N, Sahaf B, Abramian M, Spiegel JY, Kong K, Kim S, Mavroukakis S, Oak J, Natkunam Y, Meyer EH, Frank MJ, Feldman SA, Long SR, Qin H, Fry TJ, Muffly LS, Mackall CL, Miklos DB. Phase I experience with a bi-specific CAR targeting CD19 and CD22 in adults with B-cell malignancies. Blood. 2018; 132(Suppl 1):490.

98. Schultz LM, Davis KL, Baggott C, Chaudry C, Marcy AC, Mavroukakis S, Sahaf B, Kong KA, Muffly LS, Kim S, Meyer EH, Fry TJ, Qin H, Miklos DB, Mackall CL. Phase 1 study of CD19/CD22 bispecific chimeric antigen receptor (CAR) therapy in children and young adults with B cell acute lymphoblastic leukemia (ALL). Blood. 2018;132(Suppl 1):898.

99. Yang J, Li J, Zhang X, LV F, Guo X, Wang Q, Wang L, Chen D, Zhou X, Ren J, Lu P. A feasibility and safety study of CD19 and CD22 chimeric antigen receptors-modified $T$ cell cocktail for therapy of B cell acute lymphoblastic leukemia. Blood. 2018;132(Suppl 1):277.

100. Gardner R, Annesley C, Finney O, Summers C, Lamble AJ, Rivers J, Crews K, Huang L, Brown C, Mgebroff S, Lindgren C, Spratt K, Gustafson J, Johnson A, Park JR, Jensen MC. Early clinical experience of CD19 x CD22 dual specific CAR T cells for enhanced anti-leukemic targeting of acute lymphoblastic leukemia. Blood. 2018;132(Suppl 1):278. 
101. Huang L, Wang N, Cao Y, Li C, Xiao Y, Xiao M, Zhou X, Wang G, Hong Z, Zhen M, Meng W, Zhang B, Zhang Y, Marcucci G, Zhang T, Zhou J. CAR22/ 19 cocktail therapy for patients with refractory/relapsed B-cell malignancies. Blood. 2018;132(Suppl 1):1408.

102. Zhang R, He Y, Yang D, Wang Y, Feng S, Wang J, Han M-Z. Donor-derived second generation of CD19 CAR-T cell therapy for relapsed B-cell acute lymphoblastic leukemia after allogenic stem cell transplantation. Blood. 2018;132(Suppl 1):2179.

103. Sun K, Zhang X, Wang Z, Chen Y, Zhang L, Cheng W, Shi M, Huo L, Bai Y, Niu X, Guo H, Yang J, Tong C, Chang A. Allogeneic CAR-T cell therapy for treatment of relapse after Allo-HSCT in patients with refractory CML lymphoid blast crisis: significance of HLA matched donor/patient pair in the safety/efficacy of CAR-T cell therapy. Blood. 2018;132(Suppl 1):4275.

104. Testa U, Pelosi E, Frankel A. CD 123 is a membrane biomarker and a therapeutic target in hematologic malignancies. Biomarker Res. 2014;2(1):4.

105. Bras AE, de Haas V, van Stigt A, Jongen-Lavrencic M, Beverloo HB, Te Marvelde JG, Zwaan CM, van Dongen JJM, Leusen JHW, van der Velden VHJ. CD123 expression levels in 846 acute leukemia patients based on standardized immunophenotyping. Cytometry B Clin Cytom. 2018;9999:1-9.

106. Ruella M, Barrett DM, Kenderian SS, Shestova O, Hofmann TJ, Perazzelli J, Klichinsky M, Aikawa V, Nazimuddin F, Kozlowski M, Scholler J, Lacey SF, Melenhorst JJ, Morrissette JJD, Christian DA, Hunter CA, Kalos M, Porter DL, June CH, Grupp SA, Gill S. Dual CD19 and CD123 targeting prevents antigen-loss relapses after CD19-directed immunotherapies. J Clin Invest. 2016;126(10):3814-26.

107. Tu S, Deng L, Huang R, Zhou X, Yang J, Zhou W, Li M, Yue C, Wu S, Guo Z, Chang L-J, Li Y. A novel chimeric antigen receptor $T$ cells therapy strategy that dual targeting CD19 and CD123 to treat relapsed acute lymphoblastic leukemia after allogeneic hematopoietic stem cell transplantation. Blood. 2018;132(Suppl 1):4015.

108. Liu J, Zhong JF, Zhang X, Zhang C. Allogeneic CD19-CAR-T cell infusion after allogeneic hematopoietic stem cell transplantation in B cell malignancies. J Hematol Oncol. 2017;10(1):35.

109. Mali P, Aach J, Stranges PB, Esvelt KM, Moosburner M, Kosuri S, Yang L, Church GM. CAS9 transcriptional activators for target specificity screening and paired nickases for cooperative genome engineering. Nat Biotechnol. 2013;31(9):833-8.

110. Mali P, Esvelt KM, Church GM. Cas9 as a versatile tool for engineering biology. Nat Methods. 2013;10(10):957-63.

111. Mali P, Yang L, Esvelt KM, Aach J, Guell M, DiCarlo JE, Norville JE, Church GM. RNA-guided human genome engineering via Cas9. Science. 2013; 339(6121):823-6.

112. Zhang Y, Zhang X, Cheng C, Mu W, Liu X, Li N, Wei X, Liu X, Xia C, Wang H. CRISPR-Cas9 mediated LAG-3 disruption in CAR-T cells. Front Med. 2017; 11(4):554-62.

113. Knott GJ, Doudna JA. CRISPR-Cas guides the future of genetic engineering Science. 2018;361(6405):866-9.

114. Wen J, Tao W, Hao S, Zu Y. Cellular function reinstitution of offspring red blood cells cloned from the sickle cell disease patient blood post CRISPR genome editing. J Hematol Oncol. 2017;10(1):119.

115. Benjamin R, Graham C, Yallop D, Jozwik A, Ciocarlie O, Jain N, Jabbour EJ, Maus MV, Frigault M, Boissel N, Larghero J, Baruchel A, Mohty M, De Moerloose B, Bloor A, Frey NV, Zinaï A, Balandraud S, Philippe A, Fouliard S, Gauthier L, Pauly J, Konto C, Bermingham C, Veys P, Qasim W. Preliminary data on safety, cellular kinetics and anti-leukemic activity of UCART19, an allogeneic anti-CD19 CAR T-cell product, in a pool of adult and pediatric patients with high-risk CD19+ relapsed/refractory B-cell acute lymphoblastic leukemia. Blood. 2018;132(Suppl 1):896.

Ready to submit your research? Choose BMC and benefit from:
- fast, convenient online submission
- thorough peer review by experienced researchers in your field
- rapid publication on acceptance
- support for research data, including large and complex data types
- gold Open Access which fosters wider collaboration and increased citations
- maximum visibility for your research: over 100M website views per year
At BMC, research is always in progress.
Learn more biomedcentral.com/submissions

